\title{
The John Prince Research Forest: Evolution of a co-management partnership in northern British Columbia
}

\author{
by Sue Grainger ${ }^{1}$, Erin Sherry ${ }^{2}$ and Gail Fondahl ${ }^{3}$
}

\begin{abstract}
The John Prince Research Forest (JPRF) was established as a co-managed forest between Tl'azt'en Nation and the University of Northern British Columbia, as an opportunity for these partners to blend their respective ways of understanding and managing forests to contribute to ecological and social sustainability. Using four criteria of successful comanagement reported in the literature as critical to the early stages of partnership - partnership building, institutional structure, decision-making, and capacity — we discuss the JPRF's performance during the first half-decade of its existence. The JPRF's early experience provides an example of the evolution of a co-management relationship that, while facing constraints and challenges in regard to some of the criteria, has provided the foundation for a strong future partnership.
\end{abstract}

Key words: co-management, research forest, Aboriginal, First Nation, British Columbia, criteria and indicators (C\&I), community forestry, forest management, joint venture, Tl'azt'en Nation, traditional environmental knowledge, forest tenure, partnerships

\section{RÉSUMÉ}

La Forêt de recherche John Prince (JPFR) a été mise en place en tant que forêt en co-gestion entre la Nation Tl'azt'en et l'Université du Nord de la Colombie-Britannique, afin de permettre à ces partenaires d'utiliser en commun leur façon de comprendre et d'aménager les forêts dans le but de contribuer à la durabilité écologique et sociale. En utilisant quatre critères de co-gestion requis pour atteindre le succès tels que décrits dans la littérature en tant qu'éléments critiques dès les premières étapes du partenariat - l'élaboration du partenariat, la structure institutionnelle, la prise de décision et la capacité d'action - nous faisons état de la performance de la forêt de recherche après ses cinq premières années d'existence. L'expérience initiale de la JPRF constitue un exemple de l'évolution d'une relation de co-gestion qui, malgré les contraintes et les défis rencontrés relativement à certains critères, a permis l'établissement d'un solide partenariat pour les années à venir.

Mots clés : co-gestion, Autochtones, Première Nation, Colombie-Britannique, critères et indicateurs (C \& I), foresterie communautaire, aménagement forestier, co-entreprise, Nation Tl'azt'en, connaissance traditionnelle de l'environnement, tenure forestière, partenariat

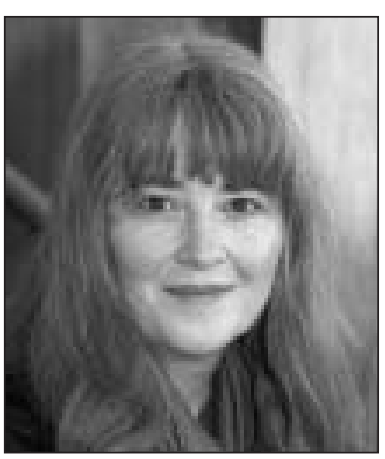

Sue Grainger

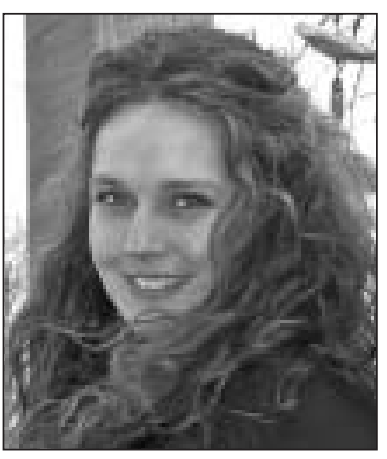

Erin Sherry

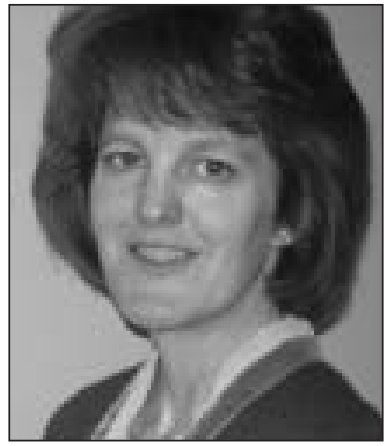

Gail Fondahl

\footnotetext{
${ }^{1}$ Manager, John Prince Research Forest, P.O. Box 988, Fort St. James, British Columbia V0J 1P0. E-mail: grainger@unbc.ca

${ }^{2}$ Manager, Northern Aboriginal Research and Development Alliance, Northern Land Use Institute, University of Northern British Columbia, 3333 University Way, Prince George, British Columbia V2N 4Z9. E-mail: sherry0@unbc.ca

${ }^{3}$ Associate Professor, Geography Program, University of Northern British Columbia, 3333 University Way, Prince George, British Columbia V2N 4Z9. E-mail: fondahlg@unbc.ca
} 


\section{Introduction}

The John Prince Research Forest (JPRF), established in 1999, represents a social and institutional experiment in co-management. Unique among university research forests, the JPRF was envisioned, initiated, and is managed in a cooperative manner between Tl'azt'en Nation and the University of Northern British Columbia (UNBC). The venture includes the management of an educational and research facility and of 13000 ha of forestland (Fig. 1).

The JPRF was conceived as an opportunity for Tl'azt'en Nation and UNBC to learn to bring together different ways of understanding and using the land as a means to integrate multiple resource values and to enhance the ecological and social sustainability of the region. It presents partners from diverse backgrounds and worldviews with research and demonstration opportunities in real-life situations. It also provides community development benefits, and educational programs that foster the personal and professional growth of future natural resource managers and community leaders.

Since 1993, the JPRF has evolved from the singular vision of a university administrator and a First Nation Band manager to a dedicated landbase of forested Crown land within Tl'azt'en Nation traditional territory, managed by a selfsupporting non-profit company, Chuzghun Resources Corporation (CRC), for the benefit of Tl'azt'en Nation and UNBC. This article reflects on the nature and structure of the early stages of this partnership ${ }^{4}$, assessing its initial operation against four key criteria for sustainable forest co-management.

\section{The Establishment of the John Prince Research Forest}

To understand the genesis of the JPRF, the origins of UNBC must be noted. It was founded in 1990 as a "university in the north, for the north," to serve the communities of northern $\mathrm{BC}$ with programs that reflected their needs. A strong, integrated Natural Resource and Environmental Studies (NRES) program was part of that vision. ${ }^{5}$ At the same time, the University had a special mandate to serve the First Nations of northern British Columbia. Indeed, the University's motto " $E n$ cha huna" (Dakelh [Carrier] for "respect for all living things") speaks directly to a commitment to respect alternative viewpoints in all endeavours, including resource management.

In 1993, the founding Dean of NRES, Dr. Fred Gilbert, conceived of a research forest that would serve the teaching and research needs of NRES. He preferred a site of at least 10 000 ha with a variety of ecosystems. Finding such a site proved difficult, as most public forest had been allocated to timber companies. However, the Ministry of Forests (MOF) identified a suitable area between Pinchi and Tezzeron lakes, some $250 \mathrm{~km}$ from UNBC in the Fort St. James Forest District (Fig. 1). This area lay within the traditional territory of the Tl'azt'en Nation.

\footnotetext{
"The use of the term "partnership" throughout the paper recognizes that, while the JPRF's goal is genuine co-management, the current relationship is a complex and evolving one that has not fully met all criteria of successful co-management - as discussed below.

${ }^{5}$ An NRES Faculty included Biology, Forestry, Fish and Wildlife Management, Geography, Resource Recreation and Tourism, and Environmental Studies programs.
}

The Tl'azt'en Nation are descendents of the Dakelh peoples who inhabited some $6500 \mathrm{~km}^{2}$ of land in north-central BC (Brown 2002). The majority of their population live in three main settlements: Tache, Binche, and Dzitlainli. Members of the Tl'azt'en Nation have been involved in commercial forestry since the mid-twentieth century; since 1984 the Nation has owned and operated Tree Farm Licence 42 (Morris and Fondahl 2002). It has been working to re-establish its control over the resources of its homeland, including timber (http://cstc.bc.ca/; Brown 2002.)

Early in the process of securing the research forest tenure, Dean Gilbert realized the need to consult with the Tl'azt'en Nation, and in 1994 approached Tl'azt'en Chief and Council. The former band manager, John Prince (in whose memory the Research Forest is named) and his associates saw opportunity in a partnership with UNBC, and agreed to work toward the establishment of a co-managed research forest. Both parties perceived benefits. UNBC recognized the proposed co-management as a way to serve First Nations needs within its service area, as well as an opportunity for some interesting research collaborations that would expand beyond the typical natural science research of most research forests to include diverse social science questions. Tl'azt'en Nation, involved in treaty negotiations, saw the co-management arrangement as providing formal legitimacy to their rights to that portion of their traditional territory, as well as local opportunities for employment, education, and training.

The JPRF was formally established in 1999. Three years later CRC initiated a research project to establish formal measures by which to judge the effectiveness of the partnership and from which to craft future strategies for development. ${ }^{6}$ The anticipated outcome of the project is a system of continuous evaluation and self-improvement.

\footnotetext{
${ }^{6}$ The project, "Criteria and Indicators of Joint Forest Management" received funding support from Forestry Innovation Investment Forest Research Program for Phases 1 and 2 (November 2002 March 2003, August 2003 - March 2004). Output from the research can be found at http://cura.unbc.ca. This research continues, with funding from the Social Sciences and Humanities Research Council (SSHRC), under the Community-University Research Alliance Program (CURA).
} 
Co-management, Joint Venture or Community Forest? While the JPRF is frequently described as a co-managed forest, it would be more accurate to describe it, in its current stage of development, as a hybrid of three systems of forest management: co-management, joint venture and community forest. Each of these management systems has specific characteristics extant in the JPRF's organization and operation.

Co-management - also called joint management, shared resource management, participatory management, or multiparty management - refers to a broad spectrum of institutional arrangements (Borrini-Feyerabend 1996). A variety of researchers have defined co-management with slightly different foci (e.g., Osherenko 1988, Berkes et al. 1991, Pinkerton 1993, Borrini-Feyerbend et al. 2000), its essential features are: involvement of two or more parties with interests and values in managing a common area or resource(s); attempts to balance relationships between individual resource users, user groups, and the state; and sharing of management responsibilities and benefits (Sherry and Myers 2002).

In Canada, co-management also frequently refers to the combination of two different management styles: traditional environmental knowledge and management systems (TEKMS) and science-based resource management systems (SBRMS) (Sherry 2002). TEKMS are based on contemporary First Nations' accumulated perceptions of their place in the world. They are an integrated complex of knowledge, practice and belief, rooted in the landscape and generations of landbased experience, and developed through observation, trialand-error experiments, spiritual insight, and the oral tradition (Legat and Brockman 1991, Grenier 1998, Berkes 1999). Often, TEKMS are tied to customary authority and communal management principles and ethics (Sherry and Fondahl 2003). SBRMS involve application of the scientific method to address issues involving a wide range of species and environmental features, their ecosystems, the underlying ecological processes, and the workings of humans (Hawley et al. 2005). TEKMS and SBRMS are both actively used throughout Canada. The relative inclusion of traditional and scientific knowledge in co-management practice is an important indicator of effective cross-cultural partnership. Co-management initiatives have met with varying degrees of success, suggesting that the goals of power-sharing, fairness, local relevance, long-term sustainability, and the integration of knowledge systems and values are difficult to achieve (Kofinas 1998, Noble 2000).

A strategic business approach for maximizing benefits while reducing risks, joint ventures in the forestry context frequently refer to forest harvesting and management initiatives undertaken by industry and local parties (including First Nations), where each party contributes capital to the venture (Curran and M'Gonigle 1998). These provide a means by which First Nations can gain entry into the resource sector, build business capacity and an economic base, and utilise the knowledge, experience, and marketing position of partners (Brubacher 1998). Operating within existing forest tenure and regulation systems, joint ventures generally focus on industrial-style resource exploitation and, as a consequence, can subvert cultural values, result in the unequal distribution of benefits within Aboriginal communities, and generate conflict between business and social objectives (Beckley and Hirsch 1997).
Community forests are locally controlled and managed for multiple objectives and community benefits according to an ecosystem-based management approach (Burda and M'Gonigle 1996). Krogman and Beckley (2002) identify three principle elements of community forestry: local control, a commitment to ecological health and sustainability, and distribution of benefits to local communities. In an Aboriginal context, community forestry aims to blend commercial forestry and traditional lifestyles, balancing economic, social and cultural values (Duinker et al. 1994, Jaggi 1997). First Nation community forestry efforts struggle with problems of representation, gaining community consensus on forest policy and practices, accessing financial resources, third party involvement, and securing an adequate landbase (e.g., size, balanced age-class structure, substantial volume of quality timber) to support a harvest sufficient to establish and operate a community forest (Treseder and Krogman 1999).

The JPRF has elements of co-management in its structure and intent, of a joint venture in its tenure and regulatory position, and of a community forest in its social objectives and management perspective. As a partnership for managing the land, the JPRF emphasizes co-operation in achieving shared goals and the combination of TEKMS and SBRMS.

\section{The Partners' Vision}

Tl'azt'en and UNBC board members crafted a joint vision statement for the JPRF:

\footnotetext{
"Internationally recognized, the John Prince Research Forest is well known for both its ecological approach to forest stewardship and its leadership in building successful partnerships between aboriginals and non-aboriginals. Integrating traditional and current scientific approaches into resource management and research has achieved long term sustainable and sound management.

The co-management approach between the University of Northern BC and the Tl'azt'en Nation serves as a model for effective partnerships. Professional capacity and high respect for both partners has been built through innovative educational approaches. The John Prince Research Forest, together with its founding partners, is recognized in Canada and beyond, for its vision, leadership and research on the cooperative management of natural resources."

(JPRF Strategic Planning Session, 29-30 October 1999)
}

The research forest was envisioned as a venue where the partners could explore collaboration, methods of combining science and tradition, natural resource questions of mutual interest, and means of improved cross-cultural education and capacity building. It was also envisaged as a model for partnership and long-term sustainability.

\section{Criteria for Co-management Success}

In a substantive review of the burgeoning literature on joint forest management and more widely on natural resource comanagement, Sherry and Fondahl (2003) identified nine broad criteria of successful partnership: institutional structure, decision-making, capacity, co-management representatives, communication, community support, partnership building, knowledge, and planned process. This paper dis- 
cusses the four criteria we consider having the greatest significance to the nascent stage of a co-management relationship - partnership building, institutional structure, decisionmaking, and capacity. ${ }^{7}$ The others assume increasing importance as the relationship develops.

\section{Partnership building}

Co-management programs and plans are only as good as the process that generated them (Borrini-Feyerabend et al. 2000). They require initial investments of time and effort to configure a relationship that is mutually agreeable. The literature suggests that a set of guiding principles and operating procedures are essential to structure interactions among participants and to direct group activities (Lewis 1993, Pomeroy and Berkes 1997). Partners need to feel that collaborative solutions will outweigh the benefits of pursuing individual courses of action. Guidelines that clearly address all partners' needs present a non-contentious foundation for partnership.

As described above, the JPRF partnership evolved in the spirit of innovation with benefits conceived for and by both parties. It was formed pro-actively, rather than in response to a current or impending resource crisis, an attribute noted as a strength in the co-management literature (Usher 1986, Huntington 1991, Chambers 1999). The partners were able to focus their discussions on future aspirations as opposed to past actions or inequities.

Early on, Tl'azt'en Nation and UNBC generated a Memorandum of Understanding (MOU; JPRF Management Committee 1995). Archived materials reveal an iterative process of revision and refinement as drafts of this document passed back and forth between the partners. ${ }^{8}$ Signed in 1995 by both parties, the MOU set out a structure for the partnership. The JPRF was to be a "cooperative venture" between UNBC and Tl'azt'en Nation. A management committee with equal number of representatives from each partner was stipulated, as was a process to appoint representatives. The MOU apportioned the economic benefits from research forest operations, specifically mentioning timber supply and Tl'azt'en employment, and defined the uses UNBC would make of the JPRF for research and training purposes.

A revised version of this MOU was embedded as a Schedule in the official tenure document issued by the $\mathrm{BC}$ MOF (JPRF Management Committee 1999). This 1999 version added a disclaimer that the agreement could not prejudice aboriginal rights and title. It expanded the duties of the management committee, required the formation of an external advisory committee, and called for the partners to form a legal entity to assume the management of the research forest. The new version altered the disposition of the economic benefits and outlined strategies around the financing of the enterprise. It redefined staffing requirements, reiterating the intention to provide Tl'azt'en employment. Finally, it added a lengthy section on the nature of forest management (requiring a sustainable ecosystem management approach). The partnership's business aspect was further formalized in the incorporation document of Chuzghun Resources

\footnotetext{
${ }^{7}$ On-going research is examining JRPF's attainment of other criteria of successful co-management as identified in the literature, and to ascertain local-level criteria of successful co-management. See footnote 5 , above.

${ }^{8}$ These documents (meeting minutes, MOU drafts) are now housed at the CRC office in Tache, BC.
}

Corporation (CRC 2000), a non-profit federally registered company owned by Tl'azt'en Nation and UNBC, established in 2001.

What began as a co-operative management committee evolved into the Board of Directors of CRC, with benefits, roles, and responsibilities clearly defined. Internal administrative policy was developed, defining the authority of staff in the running of the company. Such items as spending authority, contracting, banking and accounting protocol were developed through the Board.

The MOU, both in its initial and revised form, addressed guiding principles for the JPRF and established general operating procedures. Moreover, both partners saw benefits in pursuing a co-managed research forest - benefits that differed according to partner but appeared mutually acceptable. The process of initial partnership-building among Tl'azt'en Nation and UNBC appears to meet the criteria for successful co-management (Lewis 1993, Pomeroy and Berkes 1997).

\section{Institutional structure}

The structure of the partnership is important in creating a basis for effective co-management. Formal agreements over such issues as entitlements, roles, responsibilities and commitments appear to contribute to the effectiveness of comanagement partnerships (Prystupa 1998). Other attributes such as mandate and authority, board size, organizational structure, membership, appropriate scale, and management perspective also influence the effectiveness of partnerships (Sen and Nielsen 1996, Noble 2000, Pomeroy et al. 2001).

\section{Mandate and authority}

A number of researchers identify the requirements of a comanagement regime to define its role and its limitations (Huntington 1991, Higgelke and Duinker 1993, Roberts 1994). Chambers (1999) suggests that a written mandate should outline: 1 ) the authority of the board to manage the land and resources in question; 2) the authority of each party to participate; 3) the members' authority to represent and make decisions on behalf of their constituents; 4 ) a definition of management functions; and 5) provisions for evaluation of co-management structures and operations.

In the case of the JPRF, authority to manage the land and its timber resources is conferred through the tenure held by CRC. A Special-Use Permit (SUP), authorized through provincial land use regulations, grants its holders with the rights to use the land as a research forest in accordance with its management plan, which is signed off by the BC MOF. A Licence-To-Cut (authorized through the Forest Act) is also issued to CRC and this accords harvesting privileges. The rights granted under the tenure are subject to the rights of the other tenure holders (e.g., trapline holders, outfitters, and those with sub-surface rights).

Authority of each party to participate is bestowed through the partners' respective governing bodies. Through a series of Band Council Resolutions, Tl'azt'en Nation Chief and Council have given the Nation authority to participate in the partnership; likewise, the UNBC Board of Governors sanctions the participation of the University. Representatives are also appointed by their respective governing bodies. In Tl'azt'en's case, Chief and Council appoint each representative. UNBC's Board of Governors has delegated the selection of representatives to the University's President. The manage- 
ment functions of the Board of Directors are defined in the MOU, the tenure document, and in greater detail in the incorporation documents of CRC (Schedule B, SUP S22194, 21 December 1998).

\section{Membership and board size}

The CRC Board of Directors is comprised of equal numbers of appointees from Tl'azt'en Nation and UNBC. Representation from these two groups has evolved to include, from UNBC, faculty members (from both the physical and social sciences), administration personnel (usually from the finance department), and a community or industrial representative. From Tl'azt'en Nation, there is representation from government (usually the Chief), staff members from the natural resources, education, or economic development departments, and a member of one of the families whose keyoh ${ }^{9}$ territory coincides with the JPRF landbase.

The CRC Board of Directors is not set up to represent the diverse resource users on the JPRF landbase. Among these are guide-outfitters; private resort owners; recreationists and hunters; ranchers who hold grazing permits; agencies with management mandates (e.g., BC Ministry of Water, Land and Air Protection, BC MOF, Department of Fisheries and Oceans); Teck-Cominco Mines, which hold sub-surface rights; and the Nak'azdli First Nation, whose traditional territory embraces a portion of the JPRF. Some of these resource use groups are represented in the advisory committee; others have the opportunity for input on management activities through consultation processes associated with tenure.

Many researchers assert that the size and nature (e.g., nonhierarchical versus bureaucratic) of co-management boards affect their success (Mulvihill and Keith 1989, Pinkerton and Weinstein 1995, Pomeroy et al. 2001). In general, smaller size is considered better, as it facilitates communication and allows for more direct participation by members (Vira 1997, Kofinas 1998). However, a board should be sufficiently large and diverse to feature an appropriate level of redundancy and to represent the array of stakeholders in a region (Sherry 2002).

The CRC Board of Directors consists of six voting members and two alternates, equally divided between UNBC and Tl'azt'en Nation. One Tl'azt'en member and one UNBC member co-chair the board, and take turns chairing the meetings, the location of which rotates between Tache (the main Tl'azt'en village) and Prince George (UNBC's location). The board's size is smaller than that recommended in the literature of ten to fifteen participants (Roberts 1994). Even with this small number, meetings that accommodate the schedules of all board members can be difficult to arrange. Small working groups or advisory committees reporting to the CRC Board of Directors have been used to address complex management issues. ${ }^{10}$

\footnotetext{
${ }^{9}$ The keyoh, which is a traditional Tl'azt'en territorial management unit, is controlled by an extended family (Brown 2002). The keyoh comprises a family's hunting, trapping, and gathering area. Within the community, permission is required from the family to use resources within keyoh boundaries and, thus, the family controls the sustainability of the resources within its keyoh.

${ }^{10}$ For example, an advisory committee was struck to explore issues of compensation and share benefits arrangements for keyoh/ trapline holders whose keyohs and traplines fall within the JPRF landbase.
}

Interactive organizations

Noble (2000) suggests that in order to maintain institutional coordination and inter-organizational co-operation (thus reducing the inherent complexity and conflict associated with co-management), a horizontal institutional arrangement is most effective. Moreover, an external advisory committee is advisable where user interests are heterogeneous.

CRC's organizational structure is relatively simple, as illustrated in Fig. 2. Each partner appoints its respective representatives to the CRC Board of Directors, which makes decisions associated with the business or delegates those decisions to the staff.

In establishing CRC, the partners orchestrated an armslength relationship from each of their governing bodies in terms of the business elements of JPRF management. Specific language within their MOU and incorporation documents disallows either party from drawing economic benefit from JPRF revenues and requires re-investment of income surpluses into JPRF research and education programs. This has obviated decisions made other than to promote the stated purpose and continued fiscal viability of the venture. In the implementation of some of JPRF programs (especially the research programs), both governing bodies have interests in the process. The UNBC Research Ethics Committee and Tl'azt'en Chief and Council vet the suitability of research conducted on the JPRF and provide an outside authority on these elements of JPRF programming.

The decisions of the CRC Board of Directors in regards to forest management are subject to the constraints of the tenure and provincial laws and regulations regarding forestry, environmental protection, and cultural heritage protection. Requirements to align management with higher-level plans, such as Land and Resource Management Plans (LRMPs) ${ }^{11}$, and consultation with other resource users are incorporated in the tenure obligations.

Terms of the tenure required the formation of an external advisory committee, comprised of representatives of the forest industry, keyoh holders, the MOF, the Ministry of Environment, Lands \& Parks, the Municipal District of Fort St. James, and other local First Nations. Additional members may be invited to the advisory committee at the discretion of the management committee. This committee has, as its name implies, advisory capacity only (Schedule B, SUP S22194, 21 December 1998).

\section{Appropriate scale}

The scale of co-management should be appropriate to an area's ecology, people, and management context, as reflected in the physical size of the co-management area and the number of members included in the management board (Pomeroy et al. 2001). Noble (2000) recommends adopting the principle of subsidiarity (the idea that decisions affecting people's lives should be taken by the lowest capable organization). Ostrom (1990) found that co-management succeeds when biophysical and cultural boundaries are well-defined. The scale of a co-management unit should reflect political and ecosystem considerations, as well as the availability of resources (Hawkes 1996). Easily identifiable boundaries allow

\footnotetext{
${ }^{11}$ Tl'azt'en Nation, among other First Nations, did not participate in the LRMP process as it deemed its participation to be potentially prejudicial to its treaty claims and the process flawed.
} 


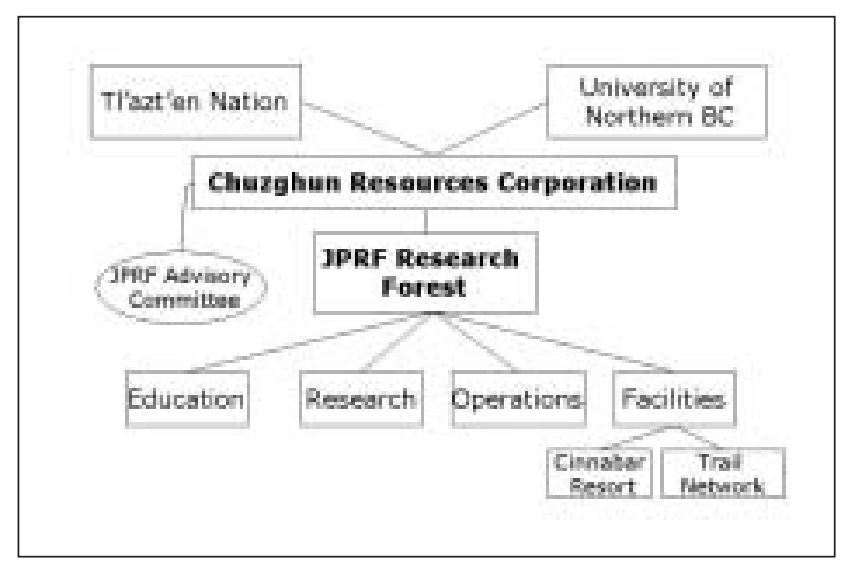

Fig. 2. John Prince Research Forest organizational structure

users to readily observe these (Pinkerton 1989, Pomeroy et al. 2001). Determining appropriate scale is also linked to legitimacy, or the extent to which resource users are willing to accept management decisions (Jentoft 1989).

As a research facility and a site for demonstration and education, JPRF's scale is comparable to other facilities. Three other Research Forests are located in BC: Alex Fraser Research Forest and Malcolm Knapp Research Forest, both owned by UBC (6000 and 5500 ha, respectively), and Aleza Lake Research Forest, co-managed by UNBC and UBC (10 000 ha). The diversity of forest habitat types and physical attributes of the JPRF provides an array of forest conditions to study. Its position as a height of land between two large lakes and its geological attributes (including a fault running through its center, and the presence of cinnabar) make it attractive to a variety of environmental scientists and students.

As an ecological management unit, the JPRF has limitations. It straddles two watersheds. Its natural disturbance regime is that of infrequent ( $80-125$ years), large-scale fire disturbance, which can reach 34000 ha (Delong and Tanner 1996). It would be entirely within the range of natural variation for the whole of the JPRF to become homogeneous in age class and stand structure. Thus, its significance at a landscape level is compromised. Likewise, its size does not correspond with the habitat requirements of large mammal species: wildlife management within the JPRF must be coordinated with bordering resource users to achieve meaningful management results.

The JPRF comprises $2 \%$ of Tl'azt'en traditional territory. It embraces parts of several keyoh areas. Other land uses and tenures began to jeopardize traditional forms of land stewardship in the early $20^{\text {th }}$ century. The 1920 s brought the introduction of registered traplines, which only roughly approximated original keyoh boundaries. The JPRF boundary follows neither keyoh nor trapline boundaries, and portions of it fall within an overlap or common use area jointly claimed by Nak'azdli and Tl'azt'en Nations.

\section{Management perspective}

Hawkes (1996) suggests that co-management is most likely to succeed if it ensures the protection of local ecological and cultural systems. While a co-management regime should adopt an ecosystem management perspective, considering the larger environmental context of which it is a part, it should also pro- mote the maintenance of local cultures and enhance crosscultural understanding (East 1991, Griggs 1991, Sherry 2002).

Within the MOU and tenure document is language concerning the JPRF management perspective: "The intent of management on the Forest is to ensure that it is maintained in a natural, ecologically sound, healthy condition" (Schedule B, SUP S22194, 21 December 1998). The partnership is also uniquely focussed on cultural maintenance and development. Many current research and educational programs concentrate on the maintenance of traditional environmental knowledge and its integration into forest management and educational curriculum (Mitchell 2003, Karjala et al. 2004). At the same time, from the structure and membership of the CRC Board of Directors to JPRF staffing, particular care is given to creating an atmosphere that promotes cross-cultural understanding and respect.

While the mandate and authority of JPRF's partners are clearly iterated, CRC's small size may limit the diversity of views expressed. CRC's simple and transparent structure appears to allow for a relatively efficient partnership within the constraints imposed by external requirements. The geographical scale of JPRF presents limitations for both ecological and cultural studies, while the JPRF's guiding documents elevate the importance of ecologically and culturally sustainable management.

\section{Decision-making}

The characteristics of decision-making are often the defining elements of a co-managed organization. Important components of shared decision-making include devolution of control, sense of ownership, consensus, conflict resolution and enforcement mechanisms, and incorporation of traditional systems (Sherry and Fondahl 2003).

\section{Devolution of control}

Co-management requires delegation of management authority to a local user organization, rather than its retention by external groups (Jentoft and McCay 1995, Pierce Colfer et al. 1995, Pomeroy and Berkes 1997, Hauck and Sowman 2001). Resources and management functions must be owned and controlled by the involved partners and communities. Within limits, the CRC Board of Directors has autonomy over timber resources on the JPRF. The Board's ability to manipulate forest cover and to develop access could have significant impacts on wildlife, fisheries, plants, water, and visual quality, which in turn could impact forest users. However, the autonomy of the partners is constrained by the tenure under which the JPRF is held. The JPRF is Crown land tenured to CRC; tenure grants the right to use the land for a specific purpose, but also sets restrictions on land use, the management process, and user obligations.

A Special-Use Permit (SUP) coupled with a Licence-ToCut (LC) are the tenures used for Research Forests in BC. The SUP allows the use of the land in accordance to a forest management plan, which is submitted and approved by the local District Manager of the $\mathrm{BC}$ MOF. The management plan outlines commitments to the protection of non-timber resources, the rate of cut (which must be sustainable), and reforestation obligations. The SUP also requires that the permit holder must comply with the BC Forest Act and Forest Practices Code, and associated regulations (Special Use Permit S22194, effective 1 January 1999). 
Through the Forest Practices Code, licensees are required to reference higher-level plans in their forest management plan. Higher-level plans (such as LRMPs) can set restrictions on land use. Other landscape-level initiatives such as Old Growth Management Areas, Visual Quality Classifications, and Wildlife Management Areas may provide external restrictions on the conduct of JPRF co-management. CRC is likewise restricted, through its tenure, from impacting holders of other types of licenses, specifically trapline holders and outfitters.

Not withstanding forestry legislation, the JPRF has enjoyed some measure of autonomy. Its management committee (CRC's predecessor) participated in crafting Schedule $\mathrm{B}$ of its tenure document, which defined the partnership, the management intent, and the type of research and educational activities it proposed. The committee also crafted its own Forest Management Plan and defined the level of cut. The BC MOF imposed the condition that the JPRF should contribute to the provincial timber supply; that is, that harvesting must occur and the logs sold on the provincial timber market. Consequently, the CRC Board of Directors must actively manage the timber, albeit at a rate of its choice as long as it is sustainable.

\section{Keyoh member rights}

Consideration of individual versus collective property rights is necessary in a co-management arrangement (Pomeroy et al. 2001). In the case of the JPRF, it has been necessary to reconcile the rights of individual families over the management of the land within their keyohs with communal rights of Tl'azt'en Nation to its traditional territory, and the shared use of the forest for social, cultural, and economic purposes for the Nation as a whole.

The CRC Board of Directors has attempted to do this through a policy of shared benefits that gives priority to members whose keyohs overlap with the JPRF landbase. The shared benefit program provides for representation of a Tl'azt'en trapline holder (whose trapline overlaps with JPRF land ${ }^{12}$ ) on the CRC Board of Directors, participation of keyoh members in the development of the Forest Management Plan, preferential hiring where qualified for employment on the JPRF, and a capital fund to enhance trapline resources and use. Building cabins and trails, and wildlife enhancement programs are among the types of benefits proposed.

\section{Sense of ownership}

Active and continuous participation of co-management partners in planning, decision-making, implementation and evaluation is essential to generating a sense of ownership and commitment to the process (Pomeroy et al. 2001). Noble (2000) differentiates between conceptual control (e.g., planning) and active control (e.g., hands-on management).

Partners participate in the CRC at three levels: business, land management, and implementation. Each of these includes elements of conceptual and active control. The Board of Directors makes decisions that range from strategic pro-

\footnotetext{
${ }^{12}$ Thorny legalities have necessitated the recognition of trapline holders (versus keyoh members) in certain instances, though when possible JPRF policies are directed toward the keyoh members. (The registered trapline holder for each of the three Tl'azt'en traplines which overlap the JPRF landbase is also a member of one of the keyohs).
}

gram planning (e.g., the type of programs) to financial decisions concerning budget allocations and capital acquisitions to administrative policies. Individual board members periodically assume information-gathering tasks to aid the decisionmaking process. To ensure active participation, regular board meetings are held approximately every six to eight weeks.

To date, land management plans for the JPRF have been generated by the non-Aboriginal Forest Manager in co-operation with various interested parties, including keyoh holders, and have been reviewed by the CRC Board of Directors and the Tl'azt'en Natural Resource Department. Adoption of this approach reflected time and monetary constraints in JPRF's early years, rather than a conscious decision on the part of the Board and staff. The Forest Management Plan is a twenty-year plan, renewable every five years. As the next planning cycle is imminent, the intent is to form a committee of technical staff (both Aboriginal and non-Aboriginal), keyoh holders, Tl'azt'en Natural Resource Department staff, and other interested community members, to collaboratively develop the plan.

Forest management on the JPRF is implemented by a staff of four full-time employees, divided equally between Tl'azt'enne and non-Tl'azt'enne. The intent is that the actual running of the research forest is shared between Aboriginal and non-Aboriginal staff, answering to a management board of similar cultural composition. Implementation of forest operations has engaged both Aboriginal and non-Aboriginal members of the local community in a variety of activities, including harvesting, silviculture (planting, brushing and site preparation), and forest health activities. In addition, CRC owns and operates a rustic hunting and fishing resort within the JPRF; seasonal staff there include both Aboriginal and non-Aboriginal persons.

Participation at these various levels has generated a strong sense of JPRF ownership among a sector of UNBC faculty and Tl'azt'enne. ${ }^{13}$ However, many Tl'azt'en and UNBC members are not fully aware of the forest and its functions. Through a variety of projects and promotions (e.g., community open-houses in Tache, information sessions at UNBC), Tl'azt'en and university personnel are working to increase the JPRF's profile within both communities.

Consensus, conflict resolution and enforcement mechanisms An effective decision-making mechanism is a requirement of any co-management venture. Researchers have identified consensus and informed agreement as the optimal methods for decision-making (Landmann 1988, Berkes 1989, Pinkerton 1989, Peter and Urquart 1991, Kofinas 1998, Singleton 1998).

The only formally defined decision-making mechanism is documented in CRC's incorporation bylaws: a majority vote is required to pass a motion and at least one representative of each of the partners must vote with the majority. In actuality, the CRC Board of Directors has adopted a consensus decision-making model with round-table discussion of alternatives and active information gathering and sharing where required.

Formal conflict resolution procedures, identified proactively, are recommended by co-management practitioners

\footnotetext{
$\overline{{ }^{13} \text { As determined through interviews with } 16 \text { Tl'azt'en members }}$ and 15 UNBC faculty. Interviews were conducted as part of ongoing research on local-level criteria and indicators of successful forest co-management: see footnote 5 .
} 
to encourage dialogue between divergent interests and promote constructive problem-solving and compromise (White 1999, Borrini-Feyerabend et al. 2000, Sherry 2002). A formal mechanism for conflict resolution has not been identified for the JPRF. In the single case where the CRC Board of Directors could not achieve consensus on a course of action, direction was sought from the governing body of the partner whose representatives were in disagreement.

Monitoring and enforcement of co-management decisions by those most affected is an effective means of ensuring co-management success (Ostrom 1990, Witty 1994, Hood et al. 1997, Sunderlin and Gorospe 1997, Vitug 1997). To date, the details of land and resource management decisions on the JPRF have essentially been delegated to staff, who must meet the broad management objectives of the CRC. Beyond reporting to the CRC Board of Directors on the state of operations, and to the keyoh holders on management plans, there is no formal monitoring mechanism or body identified to review and evaluate the process or outcomes of co-management. This deficiency is being addressed through current research, the central objectives of which are to identify locally defined criteria and indicators of co-management, then develop a monitoring strategy to determine whether these are being achieved on the JPRF.

\section{Incorporation of traditional systems}

Traditional governance approaches, such as decision-making mechanisms, representative systems, resource access and allocation rules, and partnership building activities, have much to add to contemporary co-management arrangements (Sherry and Fondahl 2003). Incorporation of such cultural and social elements serves to promote social integration and community vitalization (Fisher 1995, Jentoft et al. 1998, Nurse and Kabamba 2000).

The Tl'azt'en Nation government was set up according to the Indian Act and Department of Indian Affairs requirements for band incorporation (Brown 2002). Its official management systems reflect this bias. The traditional Carrier social organization survives but is less observable in formal business dealings.

Acknowledgement of the traditional rights of keyoh holders, a position for at least one keyoh member on the CRC Board of Directors, and keyoh holders' participation in land management planning are attempts at incorporating elements of traditional Carrier land stewardship into JPRF comanagement. As indicated above, Tl'azt'en keyoh holders whose lands coincide with the JPRF landbase also can access a shared benefits program, which recognizes their special connection to that specific territory. The JPRF might profit by the increased use of existing Tl'azt'en cultural capital (the product of history, tradition, local knowledge, and established values). Depending on Tl'azt'en Nation's objectives and future initiatives concerning reclamation of traditional forms of governance, JPRF co-managers may need to focus on further employing or contributing to the strengthening of local management institutions. ${ }^{14}$

\footnotetext{
${ }^{14}$ Research is under way to identify key Tl'azt'en values for managing JPRF for cultural, social, economic and ecologic values (to use Western labels). The research itself also involves a co-management model, governed by Tl'azt'en and UNBC researchers (see http://cura.unbc.ca for more information).
}

It should be noted that at present the language of the partnership is entirely English. While Tl'azt'en community members underscore the importance of reviving the Dakelh language, relatively few individuals in the community are currently able to converse in Dakelh, with the majority of these being elderly. However, concerted attempts to reintroduce Dakelh seem to be altering this situation in the last few years. Limited current gestures such the use of Dakelh place names for institutions (e.g., Chuzghun Resource Corporation) and on signage may over time give way to increased usage, as Tl'azt'enne themselves become more fluent and demand that their language be used.

While devolution of control over decision making is somewhat constrained by JPRF's tenure, a certain level of autonomy has allowed CRC to attempt to act innovatively, for example in using a consensus model, and by acknowledging traditional territorial governance (if in a limited fashion). $\mathrm{CRC}$ may need to respond to increased pressures to inculcate traditional mechanisms of Carrier governance in the future. The buy-in of larger sections of both communities, along with continued attention to equitable sharing of power, will be important to successful co-management.

\section{Capacity}

Without the means to carry out co-management, even the best intentioned and organized partnerships can fail. Funding, effective facilitation, administrative and external support are components of the capacity required to support co-management (Sherry and Fondahl 2003).

\section{Funding}

Secure, long-term funding is seen as essential to support the activities of a co-management organization (Osherenko 1988, Notzke 1995). Participants need to have equal access to funding to avoid marginalization. Secure internal budget sources are important to avoid failure (Pomeroy et al. 2001).

The primary funding for the JPRF originates from log sales from the forest. Additional project funding derives from grants initiated through proposal writing. CRC is selfsupporting, receiving no financial contributions from either partner.

Funding sources are a significant factor in determining comanagement success. Witty (1994) and Chambers (1999) suggest that long-term government funding is not ideal as it can create financial dependency and undermine the autonomy of a co-management board. Sherry (2002) elaborates further that funding that is either generated by the partnership or contributed by the partners promotes a sense of ownership.

To some extent, the province subsidizes the operation of the JPRF and other Research Forests; stumpage is charged at minimum rate. ${ }^{15}$ This reduced stumpage recognises the higher per unit costs associated with operational research and is granted as part of the tenure arrangement. Does subsidization through a stumpage allowance compromise the auton-

\footnotetext{
$\overline{{ }^{15} \mathrm{~A} \text { forestry policy advisor to Tl'azt'en Nation feels that it is impor- }}$ tant to offer an alternative interpretation (and one being argued in both Canadian and US courts): that the government (in this case provincial) is being subsidized by Tl'azt'en Nation, through receiving stumpage from timber cut on Tl'azt'en traditional territory prior to settlement of treaty.
} 
omy of JPRF co-management decision-making? This question is analogous to the issue of whether holding Crown tenure compromises the management intent. Both the tenure and base funding conditions can be construed as forfeiting some of the CRC Board of Directors' autonomy. Logging must occur on the JPRF (i.e., the Board cannot decide to not $\log$ ). Yet plans to implement alternative forest practices may vary from established standards. The fact that funding is selfgenerated through logging and proposal writing does promote a sense of partnership and self-determination.

Within the MOU and embedded in the tenure is a restriction on either partner benefiting directly from surplus revenues of the JPRF. All surpluses must be re-invested into the JPRF's research and educational programs. This proviso helps to guard against rival claims on the resources and unites the partners in pursuing their joint vision.

The fact that neither partner contributes financially to the partnership may be seen as detrimental, evincing of a lack of commitment. But it also has the effect of levelling the playing field, thwarting any perceptions that the "richer" partner should contribute more, which could disrupt power-sharing and the equitable distribution of responsibilities and benefits.

\section{Effective facilitation and administrative support}

A key goal of co-management is to create a balanced partnership among diverse people. Marked power imbalances, longstanding conflicts, communication problems, or diverse cultural backgrounds can diminish the effectiveness of the co-management partnership (Groot and Maarleveld 2000). Various authorities have identified the need for a neutral facilitator to advance the working relationship between partners and other stakeholders, through team-building and motivation, enforcement of group principles and rules, logistical arrangements, communications, mediation and other activities (Fisher 1995, White and Nair 1999).

The CRC Board of Directors is a diverse group in terms of culture, education, work and life experience, and socio-economic factors. Group dynamics have generally tended toward cordial politeness and mutual respect. An external facilitator has been engaged on a few occasions. Frequently the Forest Manager assumes facilitation functions.

Sherry (2002) identifies administrative support as the cornerstone of an effective co-management board in terms of maintaining group performance and sustaining a prominent profile for the organization. Support staff are seen as essential in terms of arranging logistics, providing coordination services, offering technical support, and managing public relations. The JPRF has offices at both UNBC campus and Tl'azt'en Nation. Staff responsibilities include the implementation of Board decisions as well as organizational duties around the functioning of the Board.

\section{External support}

External support provided by non-governmental organizations, academic or research institutions, governmental agencies, or interest groups can be helpful in expediting co-management (Laverack 2001, Pomeroy et al. 2001). These groups can function as fundraisers, researchers, information providers, advocates, advisers, volunteers, and promoters. They can provide training, expertise, public relations or, by association, impart credibility to a co-management organiza- tion (Murray 1995). They should operate as animators and catalysts (Kiiti and Nielsen 1999), and their involvement should be of a temporary nature toward a specific end (Sekhar 2000).

Since the inception of the JPRF, the only entity that has served in this capacity is the JPRF external advisory committee. An implicit concern that additional partners might assume power within the board and diminish the equality of the partnership contributed to this decision. External offers of collaboration to meet specific ends were sometimes rebuffed. Yet, no community or organization can hope to encompass the full complement of talents, skills, knowledge, and resources needed for co-management. Experience highlights the role of external agents as one of initiating social learning and capacity development (Wily 1999, Taylor 2000). The CRC Board of Directors may be well served in the future to engage external groups as allies in achieving and supporting co-management decisions. However, caution in the recruitment of external support is well justified; it must be culturally sensitive, oriented to facilitative approaches, and tolerant of local needs and priorities (Pomeroy et al. 2001).

External acceptance of a co-management arrangement by the local government and local elites is seen to be important in its viability. Cases cited in the Philippines, Indonesia, and Papua New Guinea demonstrate the vulnerability of co-management entities if local authorities are not included or fail to participate in the process (Vitug 1997, Thompson 1999, Wily 1999, Montagu 2001). Through the JPRF tenure arrangement, the $\mathrm{BC} \mathrm{MOF}$ has supported the co-management arrangement. By incorporating the partners' MOU as a schedule within the tenure document, it acknowledged that the JPRF would be managed jointly by Tl'azt'en Nation and UNBC, and in transferring the tenure into the name of Chuzghun Resources Corporation, it further recognized the management partnership and its intent.

\section{Summary}

In this paper, we have looked at four elements identified in literature as contributing to effective partnership formation and thus are critical to successful co-management: partnership building, institutional structure, decision-making and capacity. We have considered how the JPRF has evolved in reference to these, and implicitly, how it is moving toward meeting its vision statement in terms of providing "vision, leadership and research on the cooperative management of natural resources."

Numerous challenges nevertheless face the successful development of co-management for JPRF. Perhaps most notably, in terms of institutional structure, even the small board size has not guaranteed all members attending all meetings, thus further hampering the range of management perspectives that might be voiced. JPRF staff have strived to make the research forest's activities and goals known to its partners' larger communities (Tl'azt'en Nation members and UNBC faculty, staff and students), also in order to include a greater range of interests and viewpoints; yet there is still a lack of knowledge among both populations about the research forest. This affects the building of wider sense of ownership among both communities.

At the same time, the JPRF has excelled at serving as a focus for further research and outreach partnerships among 
its members. Several projects, some instigated by Tl'azt'en Nation, some by UNBC, have utilized the extant partnership to leverage successfully for funding for research and training. These projects are contributing to the development of professional capacity among both partners' members and of mutual respect.

Although the JPRF's effectiveness as a co-management partnership has yet to be tested, it has structures in place that engender power-sharing, establish co-operation and equity, promote in-depth communication, build respect and trust among very different but legally-bound parties, and explicate the practical, everyday challenges encountered by resource users and managers. While currently fulfilling some of the criteria that have been identified as contributing to effective comanagement, the JPRF's co-management will likely improve over time, given periodic monitoring, evaluation, and change in response to local conditions.

As our research to develop local-level criteria and indicators (C\&I) of co-management success proceeds, we are hearing from a representative range of knowledgeable local people who have a direct interest in JPRF co-management about their needs, expectations, and priorities. Monitoring these C\&I is one way the JPRF will track the achievement of desired results and will link past experiences with future initiatives. This adaptive management outlook should endow Tl'azt'en Nation and UNBC with confidence to recognize their mistakes and transform them into sources of knowledge and action, take calculated risks, accept innovation, and preserve the flexible and evolving nature of their partnership.

\section{What Does the John Prince Research Forest Exper- ience Offer Others?}

In many ways, the JPRF is unique: university research forests are not common, those partnered with outside entities even less so. The formal tenure and stumpage arrangements are specific. As well, the function of the JPRF is specialized: the emphasis on research and education objectives does not readily compare to corporate objectives. Yet the joint management, which extends to business, land management and research and education objectives, is more diverse than the single-species management that typifies many co-management arrangements.

If the JPRF was set up to study an array of questions about the function of the natural world and the appropriate relationship of humans to it, perhaps its most important contribution is that of exploring effective ways of collaboration between groups with substantially different interests and cultural backgrounds. The JPRF is about finding ways that the people can work together to address the practical problems associated with managing a landbase in a way that is respectful and sustainable, developing and empowering the local community, and initiating bottom-up social and environmental reform. The lessons learned at the JPRF have more to do with business of grass-roots partnership building than they have in informing generalized policy decision-making. In reflecting on the development and structure of JPRF management, we begin to understand the evolution of relationships of this nature and tease out the commonalities that have a broader application to those hoping to work together in land management endeavours.

\section{Acknowledgements}

The authors thank a forest policy advisor provided by Tl'azt'en Nation for reviewing and commenting on the paper, Sarah Parsons for helping prepare the manuscript, and two anonymous reviewers for their helpful comments. Funding for this research was provided by Forestry Innovation Investment Contract R04-087 and the Social Sciences and Humanities Research Council of Canada's CommunityUniversity Research Alliance program.

\section{References}

Beckley, T.M. and B.H. Hirsch. 1997. Subsistence and non-industrial forest use in the lower Liard Valley. Information Report NOR-X-352. Can. For. Serv., Nor. For. Cen., Edmonton, AB.

Berkes, F. 1989. Common property resources: Ecology and community-based sustainable development. Belhaven, London.

Berkes, F. 1999. Sacred Ecology: Traditional ecological knowledge and resource management. Taylor and Francis, Philadelphia, PA.

Berkes, F., P. George and R.J. Preston. 1991. Co-management: the evolution in theory and practice of the joint administration of living resources. Alternatives 18(2): 12-18.

Borrini-Feyerabend, G. 1996. Collaborative management of protected natural areas: Tailoring the approach to the context. IUCN, Gland, Switzerland. $67 \mathrm{p}$

Borrini-Feyerabend, G., M. Taghi Farvar, J.C. Nguinguiri and V.A. Ndangang. 2000. Co-management of natural resources: Organising, negotiating, and learning-by-doing. GTZ and IUCN, Heidleberg, Germany.

Brown, D. 2002. Carrier Sekani self-government in context: land and resources. Western Geog. 12: 21-67.

Brubacher, D. 1998. Aboriginal forestry joint ventures: Elements of an assessment framework. For. Chron. 74: 353-358.

Burda, C. and M. M'Gonigle. 1996. Tree farm or community forest? Making Waves. 7(4): 16-26.

Chambers, F.G. 1999. Co-management of forest resources in the NorSask Forest Management Licence Area, Saskatchewan: A case study. Unpublished master's thesis. Univ. Calgary, Calgary, AB.

Chuzghun Resources Corporation (CRC). 2000. Incorporation Documents. Unpublished documents.

Curran, D. and M. M'Gonigle. 1998. Aboriginal forestry: Community management as opportunity and imperative. Univ. Victoria, Victoria, BC. 43 p.

Delong, C. and D. Tanner. 1996. Managing the pattern of forest harvest: Lessons from Wildfire. Biodiv. and Cons. 5: 1191-1205.

Duinker, P.N., P.W. Matakala, F. Chege and L. Bouthillier. 1994. Community forests in Canada: an overview. For. Chron. 70(6): 711-720.

East, K. 1991. Joint management of Canada's northern National Parks. In P.C. West and S.R. Brechin (eds.). Resident peoples and National Parks. pp. 333-345. University of Arizona Press, Tucson, AZ. Fisher, R.J. 1995. Issues in forest conservation: Collaborative management of forests for conservation and development. IUCN and WWF, Bellegarde, France.

Grenier, L. 1998. Working with indigenous knowledge: A guide for researchers. International Development Research Centre, Ottawa, ON. 115 p.

Groot, A. and M. Maarleveld. 2000. Demystifying facilitation in participatory democracy. IIED Gatekeeper Series no. 89. International Institute for Environment and Development, London.

Hauck, M. and M. Sowman. 2001. Coastal and fisheries co-management in South Africa: An overview and analysis. Marine Pol. 25: 173-185.

Hawkes, S.L.E. 1996. The Gwaii Haanas Agreement: From conflict to co-operation. Environ. 23(2): 87-100. 
Hawley, A.W.L., E.E. Sherry and C.J. Johnson. 2005. A biologists' perspective on amalgamating traditional environmental knowledge with resource management. BC. J. Ecosyst. \& Manag. 5(1): 36-50. Higgelke, P.E. and P.N. Duiker. 1993. Open Doors: Public participation in forest management in Canada. Report to the Canadian Pulp and Paper Assoc., Forestry Canada and Lakehead Univ., Thunder Bay. Hood, S., L. Rasaily and G.S. Timila. 1997. Community forestry: A program or a process? The interface between users and government. In M. Victor (ed.). Community forestry at the cross-roads: Reflection and future directions in the development of community forestry. RECOFTC Report No.16. pp. 165-174. Bangkok.

Huntington, H.P. 1991. Management and regulation of local subsistence hunting in Northern Alaska. Unpublished doctoral dissertation. Univ. Cambridge and Scott Polar Research Institute, Cambridge, UK. Jaggi, M. 1997. Current developments in Aboriginal forestry: Provincial forest policy and Aboriginal participation in forestry in Ontario. Int. J. Ecofor. 13(1): 13-20.

Jentoft, S. 1989. Fisheries co-management: delegating government responsibility to fishermen's organizations. Marine Pol. 13(2): 137-154.

Jentoft, S. and B.J. McCay. 1995. User participation in fisheries management: lessons from international experiences. Marine Pol. 19(3): 227-246.

Jentoft, S., B.J. McCay and D.C. Wilson. 1998. Social theory and fisheries co-management. Marine Pol. 22(4-5): 423-436.

John Prince Research Forest (JPRF) Management Committee. 1995. Memorandum of Understanding. Unpublished document. John Prince Research Forest (JPRF) Management Committee. 1999. Memorandum of Understanding. Unpublished document. Karjala, M., E.E. Sherry and S.M. Dewhurst. 2004. Criteria and indicators for sustainable forest planning: a framework for recording Aboriginal resource and social values. For. Pol. \& Econ. 6(2): 95-110. Kiiti, N. and E. Nielsen. 1999. Facilitator or advocate: What's the difference? In S.A. White (ed.). The art of facilitating participation: Releasing the power of grassroots communication. pp. 52-67. Sage, Thousand Oaks, CA.

Kofinas, G.P. 1998. The costs of power sharing: Community involvement in Canadian Porcupine caribou management. Unpublished doctoral dissertation. UBC, Vancouver, BC.

Krogman, N. and T. Beckley. 2002. Corporate bail-outs and local buyouts: pathways to community forestry? Society and Natural Resources 15: 109-127

Landmann, P. 1988. Co-management of wildlife under the James Bay Treaty: the hunting, fishing, and trapping co-ordination committee. Unpublished master's thesis. U. of Laval. Quebec City.

Laverack, G. 2001. An identification and interpretation of the organizational aspects of community empowerment. Com. Dev. J. 36(2): 134-145.

Legat, A. and A. Brockman. 1991. Report of the Traditional Knowledge Working Group. Department of Culture and Communication, Government of NWT, Yellowknife, NT.

Lewis, M. 1993. Finding facts: the recovery of First Nation selfreliance requires building local organisational capacity. In $\mathrm{D}$. Weir (ed.). Community-based resource development and stewardship. pp. 2-8. Centre for Community Enterprise, Port Alberni, BC.

Mitchell, R. 2003. Yunk'ut Whe Ts'o Duleh (We Learn from our Land): Discussion Paper \& Curriculum Development for an Outdoor Education Culture-based Science Camp. Unpublished report. Fort St. James, BC.

Montagu, A.S. 2001. Reforming forest planning and management in Papua New Guinea, 1991-94: Losing people in the process. J. Env. Plan. \& Man. 44(5): 649-662.

Morris, P. and G. Fondahl. 2002. Negotiating the production of space in Tl'azt'en territory, Northern British Columbia. Canadian Geographer 46(2): 108-125.
Mulvihill, P.R. and R.F. Keith. 1989. Institutional requirements for adaptive EIA: The Kativik Environmental Quality Commission. Environmental Impact Assessment Review 9: 399-412.

Murray, W. 1995. Lessons from 35 years of private preserve management in the USA: The preserve system of the Nature Conservancy. In J.A. McNeely (ed.). Expanding partnerships in conservation. pp. 197-205. Island Press, Washington, DC.

Noble, B.F. 2000. Institutional criteria for co-management. Marine Policy 24: 69-77.

Notzke, C. 1995. A new perspective in aboriginal natural resource management: co-management. Geoforum 26: 187-209.

Nurse, M. and T. Kabamba. 2000. Defining institutions for collaborative mangrove management: A case study from Tanga, Tanzania. IUCN Regional Office for East Africa, Nairobi, Kenya.

Osherenko, G. 1988. Sharing power with native users: Co-management regimes for Arctic wildlife. Canadian Arctic Resources Committee, Ottawa, ON.

Ostrom, E. 1990. Governing the commons: The evolution of institutions for collective actions. Cambridge University Press, Cambridge, UK. 280 p.

Peter, A. and D. Urquart. 1991. One caribou herd, two native cultures, five political systems: Consensus management of the Porcupine Caribou range. Transactions of the 52nd North American Wildlife and Natural Resource Conference. pp. 321-325.

Pierce Colfer, C.J., R. Prabhu and E. Wollenberg. 1995. Principles, criteria, and indicators: Applying Okham's Razor to the peopleforestry link. Working Paper No.8. CIFOR, Jakarta.

Pinkerton, E. 1989. Co-operative management of local fisheries: New directions for improved management and community development. UBC Press, Vancouver, BC.

Pinkerton, E. 1993. Co-management efforts as social movements: The Tin Wis Coalition and the drive for forest practices legislation in British Columbia. Alternatives 19(3): 33-38.

Pinkerton, E. and M. Weinstein. 1995. Fisheries that work: Sustainability through community-based management. David Suzuki Foundation, Vancouver, BC. 199 p.

Pomeroy, R.S. and F. Berkes. 1997. Two to tango: The role of government in fisheries co-management. Marine Pol. 2(5): 465-480.

Pomeroy, R.S., B.M. Katon and I. Harkes. 2001. Conditions affecting the success of fisheries co-management. Marine Pol. 25: 197-208.

Prystupa, M.V. 1998. Barriers and strategies to the development of co-management regimes in New Zealand: The case of Te Waihora. Human Organization 57(2): 134-144.

Roberts, K. 1994. Co-management: Learning from the experience of the Wildlife Management Advisory Council for the Northwest Territories. Unpublished master's thesis. U. of Calgary. Calgary, AB. Sekhar, N.U. 2000. Decentralized natural resource management: From state to co-management in India. J. Env. Plan. \& Manage. 43(1): 123-138.

Sen, S. and J.R. Nielsen. 1996. Fisheries co-management: A comparative analysis. Marine Pol. 20(5): 405-418.

Sherry, E.E. 2002. Constructing partnership: A Delphi study of shared resources management in the northern Yukon. Unpublished doctoral dissertation. University of Northern BC, Prince George, BC. Sherry, E.E. and G. Fondahl. 2003. Criteria Affecting the Success of Co-management: New directions for improved forest management partnerships in BC. Unpublished report, Univ. Northern BC, Prince George, BC. 98 p.

Sherry, E.E. and H.M. Myers. 2002. Traditional environmental knowledge in practice. Soc. \& Nat. Res. 15: 345-358.

Singleton, S. 1998. Constructing co-operation: The evolution of institutions of co-management. U. of Michigan Press, Ann Arbor, MI. 165 p.

Sunderlin, W.D. and M.L.G. Gorospe. 1997. Fishers' organizations and modes of co-management: The case of San Miguel Bay, Philippines. Human Organization 56(3): 333-343. 
Taylor, P.L. 2000. Producing more with less? Community forestry in Durango, Mexico in an era of trade liberalisation. Rural Sociol. 65(2): 253-274.

Thompson, H. 1999. Social forestry: An analysis of Indonesian forestry policy. J. Contemp. Asia 29(2): 187-201.

Treseder, L. and N. Krogman. 1999. Features of First Nation forest management institutions and implications for sustainability. For Chron. 75(5): 793-798.

Usher, P.J. 1986. The devolution of wildlife management and the prospects for wildlife conservation in the Northwest Territories. Policy Paper No. 3. Canadian Arctic Resources Committee, Ottawa. 139 p. Vira, B. 1997. Deconstructing participatory forest management: Towards a tenable typology. Oxford Centre for the Environment, Ethics and Society, Oxford.
Vitug, M.D. 1997. The politics of community forestry in the Philippines. J. Env \& Dev. 6(3): 334-340.

White, S.A. (ed.) 1999. The art of facilitating participation: Releasing the power of grassroots communication. Sage, Thousand Oaks, CA. White, S.A. and K.S. Nair. 1999. The catalyst communicator: Facilitation without fear. In S.A. White (ed.). The art of facilitating participation: Releasing the power of grassroots communication. pp. 35-51. Sage, Thousand Oaks, CA.

Wily, L. 1999. Moving forward in African community forestry: Trading power, not use rights. Soc. \& Nat. Res. 12: 49-61.

Witty, D. 1994. Co-management as a community development tool: The practice behind the theory. Plan Can. (Jan): 22-27. 